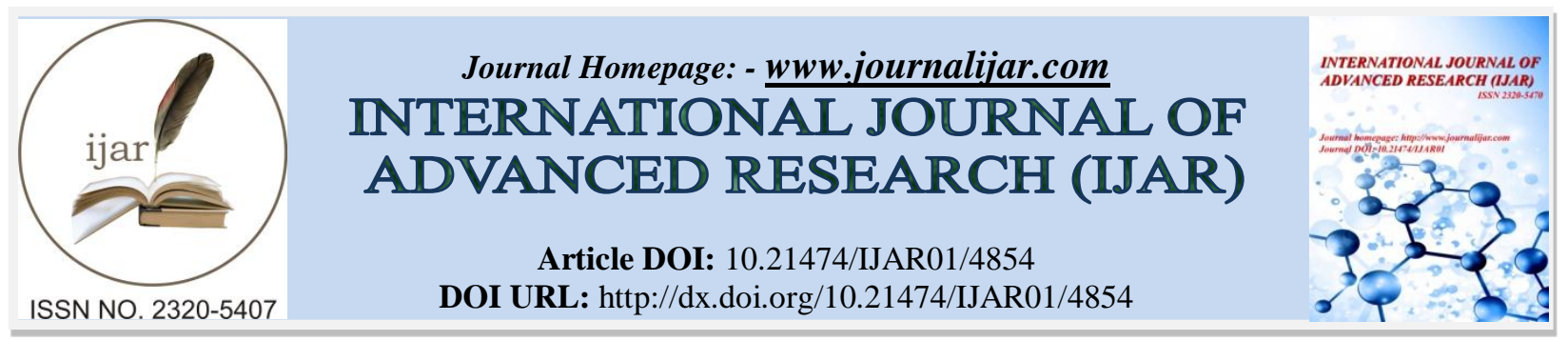

RESEARCH ARTICLE

\title{
OLD AGE: A LOOK THROUGH HIGH SCHOOL STUDENTS.
}

Jaqueline Guadalupe Guerrero Ceh ${ }^{1}$, Luz Virginia Pacheco Quijano ${ }^{2}$ Miriam Fajardo ${ }^{3}$, Axel Dzib García ${ }^{4}$, Ana Rosa Can Valle ${ }^{1}$, Luis Armando Pérez Dzul ${ }^{5}$ and María de la Luz Romero Orozco ${ }^{1}$.

1. Research Professor, Faculty of Nursing, the Autonomous University of Campeche, Mexico.

2. Professor of Research at the Faculty of Humanities of the Autonomous University of Campeche, Mexico.

3. Research Professor of the General Academic Coordination, the Autonomous University of Campeche, Mexico.

4. Intern of the Degree in Gerontology of the Faculty of Nursing of the Autonomous University of Campeche, Mexico.

5. Independent researcher, Campeche, Mexico.

\section{Manuscript Info}

Manuscript History

Received: 15 May 2017

Final Accepted: 17 June 2017

Published: July 2017x

Key words:-

Education, Youth, Perception of aging, Old age.

\section{Abstract}

Mexico is living a demographic bonus, being vital the decision making that allow concrete actions to lay the foundations on the subject of the conscience of aging. This study allows the identification of student perception levels in ten high school public schools in the City of San Francisco de Campeche, Mexico. A questionnaire on the perception of aging was applied to a population of 698 study subjects. The research focus is cuantitative, with a descriptive scope and nonexperimental transectional design. The main results obtained are: $42 \%$ of the students live with their grandmothers every day; $83 \%$ say that when they are old, they would look like their grandmothers; $62 \%$ affirm that when they are old they will enjoy life; $51 \%$ perceive that in their old age their health will be healthy, however when asked their opinion about old age, $80 \%$ express a negative perception. It is evident that when they speak of their old age they perceive it in a positive way and when asking their opinion of how they perceive old age, they express negative comments.

Copy Right, IJAR, 2017,. All rights reserved.

\section{Introduction:-}

Our world has grown old, the time has come when the countries of the "New World" would experience the reality of aging populations like the "Old World" countries, who have extensive experience in the challenges and challenges they have faced each day, with its old and old populations. Given this scenario of the increase in life expectancy, which all continents are experiencing, it is imperative to learn from countries that are already living with high percentages of their population in the stage of old age and old age, among which are: Japan And Germany, countries example of public policies worthy of being followed by the Latin American Governments that are living the demographic transition. The issues of education and health are a priority for Asian and European countries, and it is important that they be considered as guiding axes of public policies in Mexico: education and health should be a priority in the national agenda

All the countries that today have a large part of their elderly and elderly population have experienced the problem of "demographic bonus" and have used it to such an extent that the elderly today enjoy a quality of life. Some examples are Japan and Germany. In this subject and according to sociodemographic projections, Mexico is living 
its demographic bonus in the period from 2005 to 2025 , it is in an ideal stage to generate the changes that lead to a better life scenario for people in the old age and elderly population. As for the "demographic bonus", young people are a vital part of society, because they are currently part of the economically active sector of our country, which should be exploited mainly by two sectors: young people themselves and in the sector of It is important for young people to become aware of the historical moment in which they live and must face the challenges that life presents them, to lay the foundations of their future and to be aware that they are the future old and the elderly, which is why they must make good decisions now to enjoy an emotional and economic stability in their stage of old age and olderly people.

The other sectors are the politicians, the people responsible for designing the public policies of a country, which must be created taking as a reference the theme of the demographic bond, which allows laying the foundations of real public policies and with a projection into the future, prioritizing the Stability and quality of life of people in the most vulnerable stages: old age and old age; If the public policies are efficient all will enjoy the "bonus", on the contrary if they are deficient it will become "promissory note" and all will suffer the consequences.

There is an empirical perception that young people, at this stage of their human development, live and enjoy life, live only by and for the present, gives the impression that the themes of aging are little of their intere st, it seems that the most Important for them is to enjoy life and enhance their image through social networks.

The following research question arises: What is the type of perception of aging in middle school students in the city of Campeche in the 2015-2016 school year?

The objective of this research is to identify the type of perception that the students of the upper middle level have on the subject of the aging.

The importance of this research resides in the fact that it is the first time that a study of the subject of aging is carried out with students of the upper middle level in the state of Campeche, Mexico, the data obtained give the theoretical value that allows the design of future actions to favoring a culture of aging, in the sense that society as a whole must be sensitized in the knowledge of the stages of human development and that just the time and old age are part of the last stages of life that most of us will live, Being important that we live it in the best possible way, being aware that the actions we take and the decisions we make in our youth will have repercussions in our old age. This is the first time this theme has been realized in order to know the perception of young people in four aspects: Coexistence with the elderly person, Economic (saving culture), Projection to the future and Aging.

\section{Scientific Background:-}

Adolescence is a stage of human development and is composed of two parts, for the purposes of this research is of interest only the second half of the adolescent, which comprises a range of age between 14 and 17 years, have already left the stage of the Preadolescence, now have a period of family peace as family conflicts gradually go, now the discussion is usually more rational; As part of its characteristics the desire to experience new experiences outside the family. The Practical Library for parents and educators states that: "Adolescence is, above all, a social fact. The conflicts that are its own and its very duration have little to do with the process of structuring that has so far followed the psyche of the subject. "(Volume 4. Puberty and Adolescence, p. 143)

In order to know better the subject, the term perception is explained in the psychological field, which has been closely linked to the Gestalt theory. Oviedo, G. (2004) points out that:

Gestalt made a Copernican revolution in psychology by posing perception as the initial process of mental activity and not a cerebral derivative of sensory states. His theory, rooted in the philosophical tradition of Kant (Wertheimer in Carterette and Friedman, 1982), considered perception as a subjective state, through which an abstraction of the external world or relevant facts takes place.

Perception is a process that is performed by all human beings, is an internal process in which our brain associates different stimuli and creates an internal reality about what happens in our context. The first scientific studies on perception began in the nineteenth century, with the development of physiology, the first model that related the magnitude of a physical stimulus to the magnitude of the perceived event, from which the psychophysics emerged. Some of the most relevant researchers in the perception study are: 


\begin{tabular}{|c|c|c|c|}
\hline No. & NAME & STUDY AREA & CONTRIBUTION TO PERCEPTION \\
\hline 1 & Alfred Adler & $\begin{array}{l}\text { Dr., Austrian } \\
\text { child psychologist / psychiatrist. }\end{array}$ & Individual Perception \\
\hline 2 & David Marr & British Neuroscientist & Visualprocessing specialist. \\
\hline 3 & Ernst Heinrich Weber & $\begin{array}{l}\text { Psychologist and German } \\
\text { anatomist }\end{array}$ & Founder of psychophysics \\
\hline 4 & Gustav Fechner & German psychologist & $\begin{array}{l}\text { Equation that explains the relationship } \\
\text { between physical stimulation and } \\
\text { sensation (the so-called law of } \\
\text { Weber-Fechner) }\end{array}$ \\
\hline 5 & Hermann von Helmholtz & Dr. and physicist, German & $\begin{array}{l}\text { Performed acoustics and } \\
\text { Ophthalmology experiments. }\end{array}$ \\
\hline 6 & Irving Rock. & American Experimental Psychologis & Cognitive Scientific. \\
\hline 7 & James J. Gibson. & American Psychologist. & Specialist in visual perception \\
\hline 8 & $\begin{array}{l}\text { Max Wertheimer, } \\
\text { Kurt Koffka and } \\
\text { Wolfgang Köhler. }\end{array}$ & German Psychologists & Founders of Gestalt Theory \\
\hline 9 & Rudolph Arnheim. & $\begin{array}{l}\text { German psychologist and } \\
\text { Philosopher. }\end{array}$ & $\begin{array}{l}\text { Deepened in the relationship } \\
\text { between art and visual perception. }\end{array}$ \\
\hline 10 & Stanley Smith Stevens. & American Psychologist & $\begin{array}{l}\text { Author of the so-called Stevens } \\
\text { Potential }\end{array}$ \\
\hline 11 & Wilhelm Wundt. & German Dr. & $\begin{array}{l}\text { Founder of the first laboratory of e } \\
\text { xperimental psychology. }\end{array}$ \\
\hline
\end{tabular}

\section{Own source:-}

Traditionally, fields of research related to perception are organized according to the classical senses: vision, hearing, touch, smell and taste.

The process and its application in the human being occurs by three factors that work together and that depend between them, the failure of some means a negligence of great importance affecting the development and insertion of the individual in the society, Gorostiza, J. (2012) Expresses the interwoven factors: psychological, biological or physiological, and experience.

The first factor : is the psychological one, it refers to the neuronal process that the brain performs, how it interprets the stimulus that come to it from the outside world, and how it is the image that is created from these associating them with the previous experiences to be able to recognize them or learn about them. The brain does not perceive all the stimulus, it chooses the ones that it needs to survive and in front of them it acts in two ways: either it recognizes it or it does not know it. In order to detect an unknown stimulus it is necessary for the individual to pay attention and will only do so if he seeks something to satisfy a need or desire. The human being lives in a constant search to satisfy his needs and desires, the way in which he does it and what his immediate needs mark a behavior that is determined by several factors such as culture, environment, experiences, motivations Which each individual possesses within a social group. It is a social entity and depends on society, can not live outside it as it learns by imitation of its surroundings and its peers creating stereotypes and models to which it continues to create behavior from them.

The second factor: Biological or physiological factors are the internal stimuli that are captured by the five senses: sight, hearing, touch, smell and taste. The five work together, and reach the individual through different receptors, depending on what the stimulus is. It is interesting to note that although the frequency or intensity of the stimulus is similar among all, each individual will feel the stimulation enhanced in the sense that has more developed. This is both genetics and experience.

The third factor: the one of the experience, there is an individuality between people as it is the one that differentiates a social group, cultures and each subject. The way people see the outside world is different in each and it is because the brain recognizes the stimulus by association with past experiences. These vary from subject to subject, so a stimulus is perceived through this association. As each person's experience is different, the way one interprets and 
sees one stimulus, however much the same as another, differs. The model and stereotype that obeys one subject is not the same as another, even though they were born in the same culture, similar environment, same in the same family group. It depends on what the individual feels at the moment of receiving a stimulus, and what feelings or emotions the stimulus causes, varies in how he perceives it. Expectations, which enlarge as the individual develops is another fundamental factor in the act of perception, they move the user to the search for satisfaction, either a need or a desire.

The human being is a species that in itself has a history of cultures, customs and beliefs. It is a social entity and even though a culture responds to a series of beliefs and protocols, within it there are a number of people who act by themselves and are different between them. They are born, they grow, they develop, they die, and they all perceive and it is she who gives them the necessary tools for survival. This interpretation on the outside, this relation that the perception gives between the interior of an individual with the outside is different in each individual.

We perceive selectively, the subject sees what he wants to see, selects the stimuli according to his needs and his desires, and is an ongoing process. Concluding that the individual is able to select what is shown and how to do it. The way in which each person adopts a behavior is the result of a trajectory of experiences and moments in which it learns, resorting to the memories and the structure.

It is for this reason that the aim is to know the type of perception that the young students of preparatory level have towards the subject of the aging, to identify if they perceive the real scenario that is lived socially and culturally, or if it thinks that the youth takes more than the Gerontolescencia. Gerontology is a term coined by the Brazilian researcher Alexandre Kalache, who was in charge for fourteen years of the aging program of the World Health Organization (WHO), states that just as there is the stage of transition from childhood to youth, Which is called adolescence, there must be a name for the stage of transition from adulthood to old age, which has named: Gerontolescencia.

Mexico is currently in a theoretically propitious period for development, because it has a historic volume of people of working age. This is called a demographic bonus, it is also necessary to encourage formal employment to access health and social security services. "(Wong and Aysa, 2001, quoted by Villagómez, P. 2013)

Villagomez points out that in Mexico, there are two states with an advanced demographic transition: the State of Mexico and the Federal District (now Mexico City), so that these entities must have as a priority the aging of the population. Before this scenario the relevant aspects are: To depend in the study of the population of older adults, To know about the productive activity to the elderly, To strengthen the actions of prevention of health and self-care, To insert the young people in the labor field and once there Understand the importance of saving and investing for the future, Strengthen the formal labor market, which translates into a guarantee that a fair and punctual remuneration will be received for a lifetime of work, Building a balance between institutional safety nets and Family or informal. (Villagómez, P. 2013).

For its part Gutiérrez, L. (2012) explains that the health of the elderly has not been considered in the planning of public policies and specific services. Recent information is not widespread in Mexico. In the last ten years, fourteen national surveys have been carried out, including one oriented to the medical social situation of old age. It also expresses that in order to give greater certainty to the work carried out in the subject of old age, epidemiologists specialized in aging and National Observatory of Epidemiology of Aging.

Gutiérrez, L (2012) express that there is no complete epidemiological information in Mexico and that there is no mental health program for the elderly in the Ministry of Health. It also performs an analysis of the main difficulties that it has detected in Mexico, and the most relevant ones are: The lack of information, which leads to the waste of resources, inadequate services and consequently an unfavorable outcome; Chronic diseases are an expensive and important cause of disability and an inferior quality of life; The most frequent causes of chronic morbidity are arterial hypertension and diabetes, followed by heart disease, pneumopathies and neoplastic diseases, and finally malnutrition and sensory deficiencies are more prevalent.

The functional status of the elderly person is limited as the age progresses. There is no public policy that is working in this sense, there are many laws and rights that protect people aged but none is tangible, it seems to me that there is too much bureaucracy and you only think of today, thinking that maybe all of life We will be healthy and 
independent. The priority health needs of the elderly in Mexico are two: Diabetes, cardiopathies and cerebrovascular diseases; the most disabling diseases such as dementias, arthropathies and fall sequels. There is no specific program for accident prevention, detection and timely treatment of osteoporosis, or physical reconditioning to prevent falls; To this aspect adds to the already mentioned voids in the matter of aging. "In Mexico, the health sector is not at the top of public spending priorities" (Gutiérrez, L. 2012).

The risks of not acting in the sense of prevention and health promotion, will have serious financial implications. It requires an intersectoral approach, some reflections within the health sector are: how to explain that investment in social policy follows a different logic of productive investment? How to develop imaginative and creative alternatives yet unknown for efficient and low-cost care? Values that should reflect the national policy: health, life, well-being and equal opportunities.

The WHO (World Health Organization) in its global report on aging, expresses five axes of analysis: Demographic and epidemiological changes, Health characteristics in old age, intrinsic capacity and functional capacity, Key habits influencing healthy aging and Risks Environment keys. The first theme begins with the epidemiological panorama of aging, in which Japan is the only country that has more than $30 \%$ of people aged 60 or older, in the case of Europe, France was 150 years old to adapt to the increase of Its population over 60 years of age and passing from 10 to $20 \%$, followed by the countries of Brazil, China and India that will have approximately 20 years for the same transition rate. (WHO, 2015) In the second theme: Health characteristics in old age, he says that aging is characterized by the gradual accumulation throughout the life of molecular and cellular damages. The third theme: intrinsic capacity and functional capacity in the course of life, with age is losing functional capacity and increases dependency on care. In the fourth theme: Key habits that influence healthy aging. Strategies in health promotion are: healthy habits, control of metabolic risk factors, initiate at an early age and continue throughout life, reduce hypertension, improve nutrition, quit smoking and have more physical activity. In the fifth theme, key risks of the environment, the topics of emergency situations are discussed and it is explained that the functional capacity depends on the intrinsic capacity of the person, the characteristics of their environment and the interaction between these elements. (WHO, 2015)

In Developed Countries we find that the Society works from an early age, has a culture of saving and foresight for the future, so when they reach the stage of old age, they enjoy what they have saved and it is then that they are engaged in traveling through world. These countries are thinking about what can be brought to the Elderly and look at different people with different eyes: they are still productive people, their life is their job.

The scenario is different in the developing countries, where work is scarce, temporary and poorly paid, lives up to date, totally absent the idea of saving culture, this scenario is the same in all stages of growth of the Being Human, obviously in the stage of old age, the problem is even more accentuated, being a stage in which more is needed and less has, the health problems are increasing and often the economic resource is absent, causing that to increase the lists of people who survive public charity, need a pantry, even a month, that gives the Municipal or State Authority and do not mind that early morning at 4 or 5 in the morning, hoping that they get a free pantry. In these countries the priority is food and health for people over 60 years.

In the 21st century, thanks to the increase in life expectancy, it is common to find people around 50 who have their parents alive and it will be more common for their grandparents to live as well, where family harmony must adapt in the moment That one of our elders in the family, transit in the stage of a terminal stage disease. Therefore, it is important to be aware of the aging process, from an early age, by promoting a culture of respect and tolerance towards the elderly, starting work from the preschool level, seeing educational institutions as a potential to educate in the issues of health, especially in the areas of: self-care and aging. They have been behind the times when government assistance programs were expected to solve all problems, now the action is in the hands of all citizens.

The social image that the old people have is adverse, it is related to: illness, disability and severe problems. Therefore, it is important to work on raising awareness among students to foster a culture of prevention in the new generations. It is important that the promotion of self-care of health be initiated from the earliest school years, a determined action that would have great benefits for the person, the family and society. Education and health, a binomial that we must develop from all our areas of competence, to motivate prevention that privileges the culture of saving and personal health care. 
The education sector is a fundamental axis in society, offers an opportunity to reach human beings who are in the process of training, which allows to influence the awareness of fundamental issues that affect us all. Finally, we all want to live in a better world and have an active and healthy aging. All the actions that are carried out, however small they are considered are seeds that will be harvested in the very near future and all the good that we realize we will enjoy it, the negative we will live it.

The Mexican educational system lacks content and activities that promote health and social awareness issues, as well as substantive issues such as self-care and health education. It is noted that the Ministry of Public Education continues to focus on the thematic contents on education for life and peace, being the approach presented by the countries that are at the top of the PISA (Program for International Student Assessment) Coordinates the OECD (Organization for Economic Co-operation and Development), according to 2015 implementation results. Singapore leads the first place in the areas of Science, Reading Skills and Mathematics; Japan occupies places 2, 8 and 10 respectively, Germany occupies places 15, 10 and 16 respectively, Mexico occupies places 57, 55 and 56 respectively in the group of 70 countries in which the test was applied, it is clear that "Something "we are not doing well, it being a serious error to point out only teachers as the only culprits, the ideal is to add efforts and engage all actors involved, that would be a great step to a better educational scenario, not only social and health.

\section{Related Studies:-}

Among the most outstanding is the one carried out in 2010 in Venezuela by Camilli, C., et. to the. Titled: A look at the meaning attributed to old age the young students of the Metropolitan University of Caracas, Venezuela, with a sample of 406 subjects, applied an adaptation of the Arnold-Cathalifaud instrument of the University of Chile that designed for a study On the meaning of old age from the perspective of young Chilean university students in 2007. Camili, C. et. to the. (2010: 241) found that $46.6 \%$ of young people have little fear of old age, 7.6. They are very afraid and $3.7 \%$ too afraid.

Also the research titled: Jensen, F., and Vogel N. (2007) Perceptions on the Aging in Young University Students: Notes on the Self-fulfilling Prophecy, realized in Chile. They came to the conclusion that young people today in Chile perceive old age and the aging process as a stage where life seems to have become extinct and all that remains is to wait for death.

Arnold-Cathalifaud, M., Thumala, M., Urquiza, A. and Ojeda, A. (2007) in their study called: Old age from the eyes of Chilean youth: an exploratory study, It should be noted that young people have negative and pessimistic images about old age, it is also an important problem for themselves. Their images are expectations of their own future: young people will also age and face this stage with their own stereotypes, those that reproduce today.

Portela, A. (2016), in his research entitled: Negative Stereotypes on Old Age in Occupational Therapy students, carried out in Argentina, states that: Although the group of students with the least academic experience was the one with the highest levels of Negative stereotype in comparison with the other groups analyzed, there is no evidence of a clear decreasing trend in later years nor can it be said that in the last segment of the race the students' gaze on old age changes substantially. Quite the contrary, the results of this study show that in the students with the largest educational path there is a large percentage with high levels of negative stereotype about old age.

In his study entitled: Ideas on old age in students of Health Sciences of the Centro Universitario de Tonalá (Spain), Domínguez, W., Estrada, M., Ibarra, D., Villalobos, M. and Mendoza, They express that: We can conclude that the students of Sciences of the Health have stereotypes or negative ideas toward old age. In particular, students of Medicine and Public Health report a mostly negative perception in the three dimensions: health, motivational-social and character-personality; Unlike the students of Gerontology, which is expected because the formation of the latter constantly includes the promotion of positive attitudes as well as the ability to identify and eliminate negative ideas towards old age.

Aristizábal, N. (2005) entitled: Social image of the elderly in young university students, carried out in Salamanca, Spain, states that: Although there are attitudes, stereotypes and negative images of the elderly, it is also true that it is possible to modify them, Important space is the inclusion of subjects or courses on aging and old age in different degrees of higher education, since the graduates (higher education with a duration of three years) and graduates are those who in the very near future will have as their clients the elderly. 


\section{Materials and Method:-}

Hypothesis: Middle-level students have an inadequate perception of aging.

Type, Approach And Design: The research approach is quantitative, with a descriptive scope and nonexperimental transectional design.

Population: 698 students from ten middle-level public schools in the City of San Francisco de Campeche.

\section{Quotation For Obtaining The Information:-}

The corresponding administrative process was followed to obtain the permits to enter the classrooms and to be able to apply the stages of the study, the Direction of the Faculty of Nursing of the Autonomous University of Campeche, Mexico, issued an office By each of the ten schools, making known the research protocol and requesting the respective authorization to enter their spaces and apply the instrument to their student population, then waited to have the response office, with that document went to Each school to schedule the day and time at which campus management allowed students to enter.

It was integrated to a team of students of the Degree in Gerontology, they were trained and they went like applicators to each one of the schools. The general indication was to obtain a sample of 90 students for each of the schools, selecting 30 students for each semester: first, third and fifth semester, applying gender equity was careful to request fifteen by gender and by semester, The applicators came with the office in hand to schedule the application date, the instrument was applied in a single moment, finishing the application was proceeded to introduce the students the material on the subject of aging, they will have as their clients older people .

The study is integrated by two moments: the first is the application of the instrument and the second is a chat with the subject of aging, which is intended to sensitize students of that level.

\section{Instrument:}

In the absence of an instrument that integrates the four aspects of interest: Coexistence, economics, projection to the future and opinion of aging, we proceeded to design the instrument called: Survey of student perception about aging, which was piloted before a population of thirty study subjects, with similar characteristics.

Description of the instrument: The instrument is composed of twenty-four items, divided into four themes, the first is Coexistence, consisting of six items of which two are questions with dichotomous response (yes / no) and the other four are multiple choice; The second is Economy, consisting of eight items of which three have as a dichotomous choice, four multiple choice and one open question related to the name of an AFORE that they know; The third is Projection to the future, composed of nine items of which four have dichotomous response option and five are multiple choice; The fourth and last one is an open question in which it tries to know the opinion that the students have on the subject of the aging.

The values for each item that integrate the applied instrument are explained below:

Table 1:- Analysis table according to the item.

\begin{tabular}{|l|l|l|l|}
\hline ÍTEM & VALUE & OBSERVATION \\
\hline & 1 & 0 & \\
\hline 1 & YES & No & \\
\hline 2 & YES & No & \\
\hline 3 & A & C and E & You can choose up to 3 options \\
\hline 4 & A, B and D & A and D & You can choose up to 3 options \\
\hline 5 & B, C and E & B, C, D and E & \\
\hline 6 & A & A, B, C and D & \\
\hline 7 & E & A, B, C and E & \\
\hline 8 & D & NO & \\
\hline 9 & YES & A, B and D & The name of the known AFORE is written \\
\hline $9 \mathrm{a}$ & C & NO & \\
\hline 10 & YES & A & \\
\hline $10 \mathrm{a}$ & & B & \\
\hline 11 & & & \\
\hline
\end{tabular}




\begin{tabular}{|c|c|c|c|}
\hline $11 \mathrm{a}$ & A and D & $\mathrm{B}, \mathrm{C}$ and $\mathrm{E}$ & You can choose up to 3 options \\
\hline 12 & YES & NO & \\
\hline $12 \mathrm{a}$ & YES & NO & \\
\hline 13 & $\mathrm{~A}, \mathrm{~B}$ and $\mathrm{E}$ & C and D & You can choose up to 3 options \\
\hline 14 & $\mathrm{~B}, \mathrm{D}$ and $\mathrm{E}$ & $\mathrm{A}$ and $\mathrm{C}$ & You can choose up to 3 options \\
\hline 15 & YES & NO & \\
\hline 16 & & & Grouped according to option, not relevant. \\
\hline 17 & A & $\mathrm{B}, \mathrm{C}, \mathrm{D}$ and $\mathrm{E}$ & \\
\hline 18 & YES & NO & \\
\hline 19 & $\mathrm{~B}, \mathrm{C}$ and $\mathrm{E}$ & A and D & You can choose up to 3 options. \\
\hline 20 & Positive & Negative & $\begin{array}{l}\text { The comment is analyzed and given a value, taking } \\
\text { into consideration if you are thinking positively and } \\
\text { responsibly in your future. }\end{array}$ \\
\hline
\end{tabular}

The instrument is composed of four aspects:-

1. Coexistence with old or elderly people, is measured with items No. 1, 2, 3, 4, 5 and 6

2. Economics, is measured with items No. 8, 9, 9a, 10,10a, 11 and 11a

3. Projection to the future, is measured with items No. 12, 12a, 13, 14, 15, 16, 17, 18 and 19

4. Aging view, is measured with item 20.

\section{Results:-}

Next, the five most relevant items are presented, which contribute to the identification of how young people perceive or perceive themselves in old age; these items are numbers 3, 12a, 13, 14 and 20.

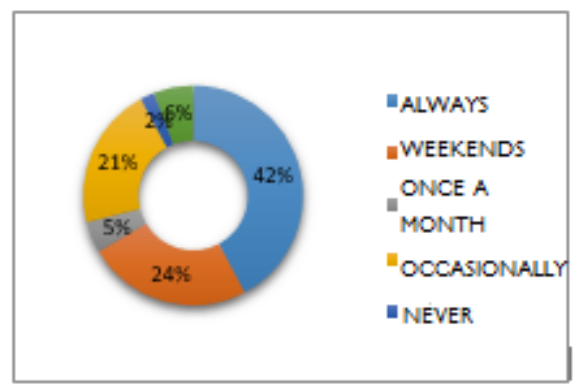

Figure No.1:- Coexistence with grandparents.

The results that reflect this figure corresponds to item No. 3 of the instrument, which asks about the frequency in which the student visits and lives with his or her Abuel@s, whether they live at home or visit frequently, having five options, Of which only the extreme values are taken into account a) Every day e) Never, the values found express that $305(42 \%)$ every day visits them and only $15(2 \%)$ never visits them.

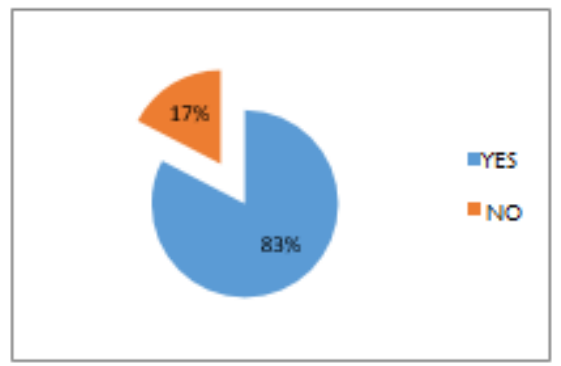

Figure 2:- Perception of his physical image in old age.

In this figure refers to item No. 12a and reflects the perception of students who in their old age would see how their grandmothers, of which $560(83 \%)$ affirm that they would look like them and $118(17 \%)$ expresses that they do not It would look like them. 


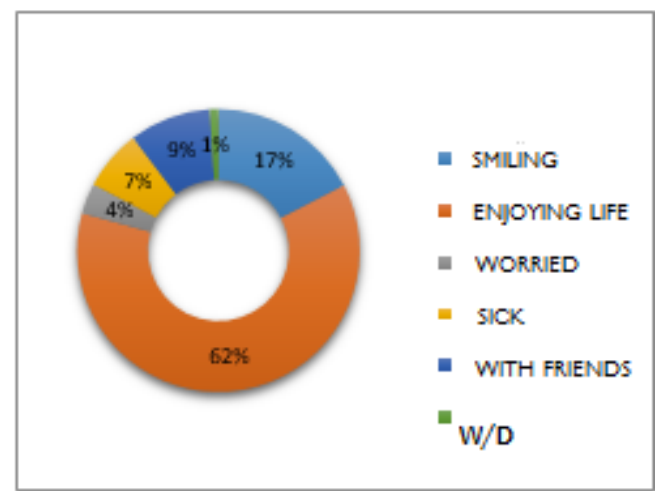

Figure 3:- Perception of his emotional image in old age.

In item \# 13 they were asked "How would you see yourself when you reach the age of your Grandparents?" Having five options of answer, taking the two extreme answers with subsections b) Enjoying life and d) Sick, obtaining 444 $(62 \%)$ and $50(7 \%)$ respectively.

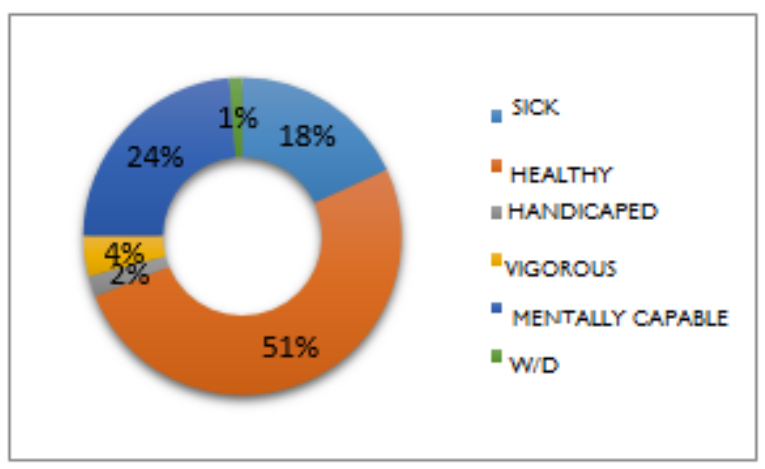

Figure No. 4:- Perception of health status in old age.

In item \# 14 they were asked, "What would your health be like when you are 70?" Having five options for answering, taking into account the two extreme responses to a) Healthy and b) Ill, obtaining 380 (51\%) and 136 (18\%) respectively.

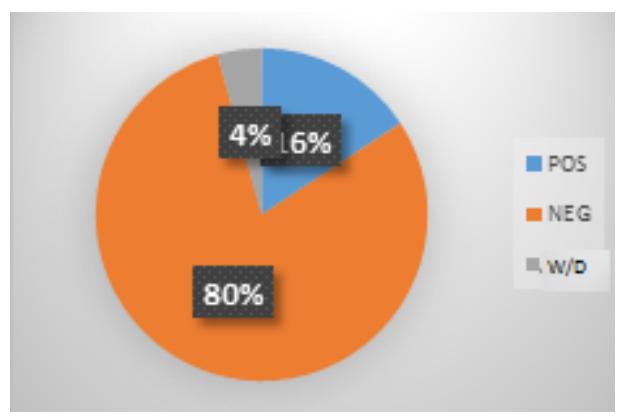

Figure 5:- Aging perception.

In item No. 20, they were asked to read a sentence written by Leonardo Da Vinci and write a commentary, which was analyzed in two aspects: positive and negative, from which it was obtained that 110 study subjects representing the $16 \%$ (110) considers old age to be positive, and $80 \%$ (558) perceive it as negative. In this item is interesting the answer found because it reflects the concern of the study subjects to be aware that what they do now that they are young will allow them to enjoy their old age.

\section{Conclusions:-}

When performing the analysis of the results, the following final conclusions are expressed according to the items: 
1. Based on the results obtained and analyzed, the research hypothesis is rejected, because the study subjects present a positive and adequate perception towards the subject of aging.

2. Study subjects still find it important to live with their grandparents, whether living with them or visiting them, this reflects that at least in this generation, older people have the company of their relatives.

3. Students perceive that their physical image in their old age will be like that of their grandparents, which indicates a certain sensitivity to the treatment that they give to the elderly, whether or not they are familiar.

4. Participants in a high percentage perceive their emotional image in their old age will enjoy life, which reflects optimism and a certain commitment now in their youth to lay the foundations of their future today.

5. Study subjects perceive that in their old age they will have a healthy state of health, which reflects confidence that now that they are young, they are doing the right thing by taking care of their health and exercising.

6. In the question asking for an opinion on a phrase, a significant majority, expresses negative aspects of old age, which reflects that they perceive that being old is being at a disadvantage with others. That is to say when it comes to thinking of them as future old people, they perceive themselves optimistically and want what is best for them in the last stages of their development, yet they are not blind to the reality of today's society, in which they perceive limitations And lack of opportunity for the old and the old.

7. We can not forget the increase in life expectancy and its social image that translates into a Mexican educational system that is poor in content and activities, social awareness, self care and health education.

\section{Recommendations:-}

This study can be taken up by researchers interested in the topic of prevention culture that allows to have a better stage in the aging stage, being interesting to apply the questionnaire of "Viejismo" of Dr. Victor Manuel Mendoza Núñez of FES Zaragoza de The UNAM, an instrument that would complement this research.

Educational institutions are advised to inform in a first stage their management authorities, their academic plant on the subject of the culture of health prevention and awareness towards the stage of old age and old age, to generate awareness in which all We will reach this stage of old age and elderly people and we must maintain our independence and health, but to get there we must work from childhood, adolescence, start at an early age and school is the ideal space to achieve it. In a second stage reach our students with the same slogan: generate a gerontological awareness.

It is also important that the people responsible for dictating public policies in the country are aware of the problems that lie ahead and actually dictate laws that promote the independence and quality of life of the old age and elderly people, the reality is that the current scenario is hopeless, so we must act now from all areas.

Unfortunately, only superficial proposals have been made and have little impact in the future, a proof of this are the current public policies are based on social assistance programs that have no hope of sustaining in the medium and long term. It is thought only to solve temporary problems, to provide social stability in the present, contributing in the generation of future instability, being worrisome the way we lead, it is necessary to create sound public policies that guarantee stability for the elder, who have room to develop Fully, that they are cared for in their health, that they are integrated into society, that they promote respect, have spaces for recreation and their spirituality, that really the stage of old age enjoy it and not be a stage in which discriminate against them and be a burden on the family or society.

\section{References:-}

1. Anderson, J. R.; Bower, G. H. (1973). Human Associative Memory (en inglés). Trad. cast. Memoria Asociativa. (1977). México: Limusa. Winston \& Sons.

2. Aristizábal, N. (2005) Imagen social de los mayores en estudiantes jóvenes universitarios, Salamanca, España.

3. Revista Pensamiento Psicológico, vol. 1, núm. 4, enero-junio, 2005, pp. 27-32. Disponible en: http://revistas.javerianacali.edu.co/index.php/pensamientopsicologico/article/view/29

4. Arnold-Cathalifaud, M., Thumala, M., Urquiza, A. y Ojeda, A. (2007) La vejez desde la mirada de los jóvenes chilenos: estudio exploratorio. Chile. Revista Última década n²7, CIDPA Valparaíso, diciembre 2007, pp. 7591. Consulta realizada el 30 de enero de 2017. Disponible en http://repositorio.uchile.cl/bitstream/handle/2250/121593/La_vejez_desde.pdf?sequence=1 
5. Bahrick, L. E.; Hollich, G. (2008). Intermodal Perception. Encyclopedia of Infant and Early Childhood Development (en inglés). San Diego, Estados Unidos: Academic Press. Consultado el 20 de septiembre de 2015.

6. Biblioteca Práctica para padres y educadores. Pedagogía y psiclogía infantil. Tomo 4. Pubertad y Adolescncia. Pág. 143.

7. Bruce Goldstein, E. (2006 (2002)). La percepción del movimiento (6 $6^{\circ}$ edición). Thomson. ISBN 84-9732-388-2.

8. Camilli, C., Millán, A. y Tirro, V. (2010) Una mirada al significado que le atribuyen a la vejez los jóvenes estudiantes de la Universidad Metropolitana de Caracas, Venezuela. Revista Anales de la Universidad Metropolitana, Vol. 10 No. 2. Páginas 227 - 251. Consulta realizada el 10 de febrero de 2017. Disponible en: http://andromeda.unimet.edu.ve/OJS/index.php/ra/article/view/39

9. Collins Discovery Encyclopedia. HarperCollins Publishers. (2005]). The process by which an organism detects and interprets information from the external world by means of the sensory receptors. Consultado el 20 de septiembre de 2015.

10. Domínguez, W., Estrada, M., Ibarra, D., Villalobos, M. y Mendoza, N. (2015). Ideas sobre la vejez en estudiantes de Ciencias de la Salud del Centro Universitario de Tonalá. Investigación y práctica en psicología del desarrollo / 1-2015 / pp. 237-243. Consulta realizada el 10 de junio de 2017. Disponible en: http://revistas.psico-ags.net/index.php/ippd/article/view/20

11. Gutiérrez, L. (2012) "La salud del anciano en México y la nueva epidemiología del envejecimiento". Instituto Nacional de Geriatría, México.

12. Goldstein, E. Bruce (2009). Encyclopedia of Perception. Sage. ISBN 978-1-4129-4081-8. Consultado el 24 de septiembre de 2015.

13. Gorostiaga, J. (2012). La percepción como medio de desarrollo del individuo. México, DF.

14. Hetherington, Mavis E.; Parke, Ross D. Infancy: Sensation, Perception and Learning. Child Psychology: A Contemporary Viewpoint (en inglés). McGraw-Hill Global Education Holdings. Consultado el 20 de septiembre de 2015.

15. Jensen, F., y Vogel N. (2007) Percepciones en torno al Envejecimiento en Jóvenes Universitarios: Apuntes entorno a la Profecía Autocumplida, realizada en Chile. VI Congreso Chileno de Antropología. Colegio de Antropólogos de Chile A. G, Valdivia, 2007 / pp. 1-14. Consulta realizada el 10 de junio de 2017. Disponible en http://www.aacademica.org/vi.congreso.chileno.de.antropologia/25.

16. Larousse. Percepción. Consultado el 20 de septiembre de 2015. Disponible en: Diccionarios.com

17. Lewkowicz, David J. (1992). Infants' response to temporally based intersensory equivalence: The effect of synchronous sounds on visual preferences for moving stimuli». Infant Behavior and Development (JAI) 15 (3): 297-324. Archivado desde el original el 1 de diciembre de 2015. Consultado el 20 de septiembre de 2015. Both age groups exhibited intersensory matching in that they looked longer ot the stimulus whose direction reversal corresponded to the sound. This was true, however, only when the sound corresponded to the visual stimulus that began to move first.

18. Maratos, O. «Trends in the development of imitation in early infancy». En T. G. Bever. Regressions in Mental Development. (En inglés). Hillsdale NJ: Erlbaum. pp. 81-101.

19. Merleau-Ponty, M. (1985). Fenomenología de la percepción. Barcelona: Planeta-Agostini. ISBN 8439522193.

20. OMS (2015) Informe mundial sobre envejecimiento y la salud. Consulta realizada el 20 de enero de 2017. Disponible en http://apps.who.int/iris/bitstream/10665/186466/1/9789240694873_spa.pdf

21. OCDE, Informe PISA. Disponible en http://www.oecd.org/pisa/pisaenespaol.htm http://www.oecd.org/pisa/pisaenespaol.htma

22. Patricia, Patricia E. Principles of gestalt psychology and their application to teaching junior high school science. Science Education (Wiley Periodicals, Inc) 57 (1): 43-53. DOI:10.1002/sce.3730570110. Consultado el 21 de septiembre de 2015.

23. Pomerantz, James R. (2003). Perception: Overview. En Lynn Nadel. Encyclopedia of Cognitive Science 3. Londres: Nature Publishing. pp. 527-537. ISBN 978-1-4129-4081-8.

24. Postman, Leo (1974). Percepción y aprendizaje. Argentina: Nueva Visión.

25. Portela, A. (2016) Estereotipos negativos sobre la vejez en estudiantes de Terapia Ocupacional. Argentina. Revista Argentina de Terapia Ocupacional. 2 (1), 3-13. Disponible en: http://www.revista.terapiaocupacional.org.ar/descargas/volumen2/Rev2\%20Art1.pdf

26. Segen's Medical Dictionary. Farlex. 2012. The constellation of mental processes by which a person recognises, organises and interprets intellectual, sensory and emotional data in a logical or meaningful fashion. Consultado el 20 de septiembre de 2015. 
27. Villagómez, P. (2013) "El envejecimiento demográfico en México: niveles, tendencias y reflexiones en torno a la población de Adultos Mayores" Instituto Nacional de Geriatría, México.

28. Zepeda, F. (2008). Introducción a la psicología. México: Persona.

\section{Appendix:}

Appendix 1. Applied instrument

\section{STUDENT PERCEPTION SURVEY ON AGING FAJARDO, GUERRERO Y MUÑOZ, 2016.}

This survey intends to know your appreciation, about the aging process. The results will be integrated into a database, for statistical analysis, for exclusive research purposes. The reliability of the information is guaranteed. Age ___ Gender ___ Educational Level

INSTRUCTIONS: for each one of the questions it indicates with an "X" an option of answer.

\section{COEXISTENCE}

1. Do you have Grandfather (mother)?

Yes

No

If your answer is NO, do not answer the numbers 2, 3, 4 and 5. Continue at number 6

2. Do you live together with your grandparents? Yes No

3. How often do you visit or live with your Grandparents?

$\mathrm{O}$ every day O Only weekendsO Once a month

O Occasionally because they live in another colony, municipality or city.

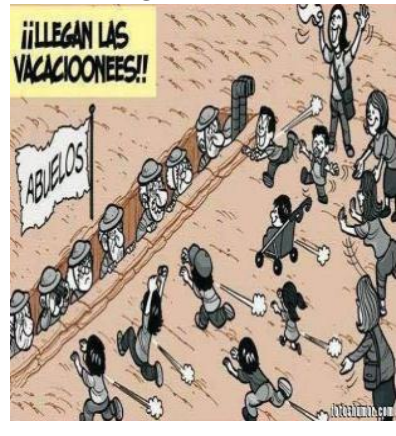

O Never

4. What is your Grandfather's name? Select only one, the most used.

O Grandfather O Grandpa O old man O Dan/Mom (a) Dad O By their name

5. What activity do you do most with your Grandparents?
O I just say hello.
O Talk
O play
O watch TV O walk

6. When you think of your Grandparents, what comes first to your mind?
Or Tenderness / Happiness Sadness
O Illness
O Fear O Indifference

\section{ECONOMIC}

7. When you want to buy what you like, from whom do you get money?
O Daddy
O Mother
O Godparents
$\mathrm{O}$ Uncles
O Grandparents

8. What do you do with the money they give you?

Write a number from 1 to 5, by degree of importance, where 1 is the most important for you. I buy sweets

_ Savings to buy: clothes or shoes

I save it to buy more expensive toys

I I keep it to help my Dads in case of an emergency I spend everything

9. Do you like to save money? O Yes O No

If your answer is yes, answer the following question, if it is continuous negative in the number 10 .

$9^{\text {a }}$ If you sabe. Where do you usually save it?

$\mathrm{O}$ In a piggy bank: "cochinito"

$\mathrm{O}$ In your house, in a place that only you know.

O On a bank card

O You give it to your Mom or any Family member to keep it for you

10. Have you ever heard of AFORE? O Yes O No

Answer the following if your answer is yes, if no, go to question 11.

10a Write the name of an AFORE

11. What do you think AFORE serves?

O It's like a bank account, just saved. O It allows me to save and enjoy my money in my old age.

11a what do you think of the Elderly people, who pack in the supermarket boxes as "cerillitos". 
O It allows having a decent occupation, socializing and having a small income.

$\mathrm{O}$ It is tiring, because they are standing long hours.

O I think when I'm old I'll be there.

O It's good, because these companies give opportunity to the Elderly.

O I do not care what happens to them.

\begin{tabular}{|l|l|}
\hline $\begin{array}{l}\text { PROJECTION } \\
\text { FUTURE }\end{array}$ & FOR THE \\
\hline
\end{tabular}

12. Have you actually looked at yourself in a mirror?
O Yes
O No
$\mathrm{O}$ Yes
$\mathrm{O}$ No

12a Have you ever thought that you will be physically like your Grandparents?

13. When you reach the age of your Grandparents, how do you think you would see?
$\mathrm{O}$ laughing
O Enjoying life
O Worried
O Sick
O With friends

14. Imagine that you are 70 years old, what would your health look like?
O Sickness
O Healthy
O Disabled
O Vigorous
O Mentally capable

15. Have you ever heard of an insurance company? O Yes O No

16. What risks do you think, which are supported by insurance companies?

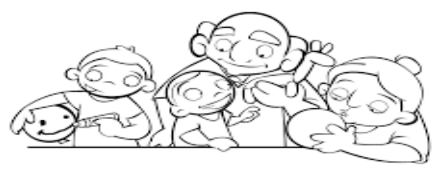

$\mathrm{O}$ Damage caused by catastrophes such as fire.

O Legal aid services.

$\mathrm{O}$ Those that affect the integrity of a person caused by an accident.

few.

O Damage caused to the insured property, whether Auto, House, Companies, Equipment, to mention a

O In case of death, disability or survival of the insured.

17. Imagine that you are 25 years old, you have stable work that allows you to save, what would you do to enjoy quality old age? Select only one option, the most important.

$\mathrm{O}$ Analyze the options, to buy a life plan with an insurer.

$\mathrm{O}$ I would get married and have many children.

$\mathrm{O}$ I would invest in my education.

O I would buy a house.

O I would buy clothing, footwear and electronics of my taste.

18. Do you know what healthy eating is? $\mathrm{O}$ Yes $\mathrm{O}$ No

19. When you hear the expression: healthy eating what do you think?

$\mathrm{O}$ In eating only fruits, vegetables and drinking lots of water

$\mathrm{O}$ In eating my cake of cochinita and a soft drink

$\mathrm{O}$ Enjoy nuts including: magnesium, vitamin E, iron, calcium and fiber

$\mathrm{O}$ Healthy eating is expensive

$\mathrm{O}$ In drinking gaseous sodas and many goodies, rich in sugars.

20. Write the first thing you think, when you read this sentence of Leonardo Da Vinci

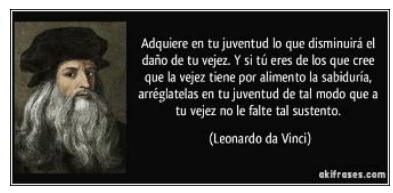

THANK YOU FOR YOUR COLLABORATION! 